\title{
EFFICIENCY IN THE MARKET FOR FINANCIAL ADVISORY SERVICES TO BUSINESSES*
}

SHAUN HARGREAVES-HEAP ${ }^{a}$, OLEKSANDR TALAVERA ${ }^{b}$

aKing's College, London

Email: s.hargreavesheap@kcl.ac.uk

${ }^{\mathrm{b} C}$ Corresponding author, University of Birmingham

Email: o.talavera@bham.ac.uk

\begin{abstract}
This paper considers whether company decisions on their advisors promote efficiency in the market for business advisory services. We employ a fixed effects measure of advisor quality and find that no finegrained measure of performance seems to influence separation and hiring decisions. We do find that, under a rule of thumb measure of advisor performance, firms are more likely to ditch "bad" and "neutral" advisors than "good" ones. Unfortunately, using the same rule of thumb measure, firms appear no more likely to hire "good" quality new advisors than could be expected by chance. As a result, in less than $10 \%$ of all separations the new hire yields an improvement in advisor quality. In short, there is a substantial amount of movement in the market with no benefit.
\end{abstract}

JEL Codes G30, G39

Keywords financial advice, performance

\section{INTRODUCTION}

Do businesses switch from financial advisors that perform poorly to better advisors? This is the core question considered in this paper, and it is important for two related reasons. First, this type of change is crucial for the functioning of any market. Of course, other behaviours also affect efficiency, but unless buyers respond to differences in supplier performance, there is no incentive for poor performing suppliers to improve or to quit the market and thus reallocate business to better advisors. For precisely that reason, buyer switching decisions have recently attracted attention in other contexts (see Giulietti et al., 2005 and Waddams and Zhu, 2016 for recent studies of consumer switching in the retail energy market). Secondly, unless purchasers switch in this way, the connection between the performance of financial advisors and their earnings is weakened. Denton (1985), for instance, offered an early model in which purchasers do not reward good performance from their advisors, which resulted in a greater price for the advice over time without an increase in quality.

It has long been understood that information markets, as in advisory services, are likely to pose difficulties for the claim that markets promote efficiency. The quality of advice can only be known with certainty (if at all) after one has acted upon it, by which time it is too late to influence the original decision (Arrow, 1963). Of course, reputation can help, but it too depends on market participants being able to identify advice that is proven good, bad, or indifferent. That may not always be possible because outcomes can depend on luck as well as skilled advice and sometimes the counterfactual of a non-advised outcome is not well defined.
For these reasons, one may hypothesize that the market in business advice is likely to be less efficient and earnings are more attributed to luck than skill than in other non-informational markets. This view may help explain why investment bankers' earnings (which depend partly on financial advice) are controversial; high earnings that are owed to skill are typically perceived as legitimate, while earnings related to "luck" are not (Balafoutas et al., 2013). However, businesses may be better placed than individuals in dealing with these difficulties. Businesses can direct more resources to assess advisor reputations and are more likely to act on these assessments than individuals are. That suggests a more efficient functioning of the advisory market and that advisor earnings are related to performance. In this paper, we delve into these two conflicting arguments and examine the relevant related evidence.

Businesses typically retain financial advisors in two capacities: for a general range of services over time and for a concrete service in relation to a specific corporate action, like an Initial Public Offering (IPO) or underwriting. Studies have been conducted on the selection of advisors for specific tasks, but there are no studies we are aware of on the switching behaviour of businesses with respect to general financial advice. This paper is dedicated to that gap in the literature. This gap is notable both because there is a market for general financial advice, but also because the results from the studies on selecting financial advisors for concrete tasks is mixed. One possible explanation for that is that these decisions are connected to advisor performance across a range of services and not just for one task. Krigman et al. (2001) find evidence that switching decisions for underwriting advisory services is influenced by the prospect 
of gaining access to a wider range of advisory services. This is not surprising (since advisors typically have expertise in an industry and can advise across a range of activities), but it means that the choice of advisor for a specific task likely depends on an advisor's general performance rather than simply in underwriting.

Krigman et al. (2001) also find little systematic evidence that recent advisor under-pricing performance affects switching decisions for this service. Likewise et al. (2010) in their study of switching behaviour find that the decision to stay/switch when banks merge is largely driven by broader considerations: in their case, by the firm's desire to avoid possible information leakage from sharing an underwriter with other firms in its industry. The prospect of moving to an advisor with a better reputation is, however, important in Krigman et al. (2001). That reputation matters, when performance on a specific task does not, might seem strange, but it is consistent with the evidence on this relationship (outside of the context of switching). For instance, while early studies of bank advice on IPOs typically found that reputable banks under price new offerings less frequently than less reputable banks (e.g. Logue, 1973; and Neuberger and Hammond, 1974), more recent studies (like Chemmanur and Krishnan, 2012) find that reputable firms tend to price further from intrinsic value. Recent studies of certification services on high yield bonds come to a similar negative conclusion on the signal provided by reputation because it seems that reputable underwriters are more often associated with downgrades and default risks (Andres et al., 2014). This is apparently recognised by bond purchasers with the result that the issuers, in effect, pay for the relatively poor service from the underwriter. However, there is contrary evidence on certification (Fang, 2005). Likewise, in studies of mergers and acquisition advisory, some studies find that employing more reputable banks yields higher returns (e.g., Kale et al., 2003); other studies find the opposite (e.g., Michel et al., 1991).

The lack of a clear relationship between reputation and performance on a specific task would not be surprising if reputation depends on performance across a range of tasks and not just a particular task. If this was the case, and, indeed reputation matters in switching, then we would expect to find that switching decisions are related to general performance. This is what we examine in relation to the choice of a general financial advisor.

The difficulty we face in addressing that question is how to measure the general quality of financial advisors. Quality is more measurable when focusing on specific actions. For example, the quality of advice for underwriting can be measured by the extent of underwriter under-pricing. A price-based measure of quality was also available to Waddams and Zhu (2016) in their study of consumer switching in retail energy markets because, with a homogenised product, price is a simple indication of the quality of a supplier's offer. Unfortunately, there is no obvious pricebased measure for the quality of general advisory services. Therefore, our approach is different. We follow the fixed effects method of Bertrand and Shoar (2003) in quantifying a manager's performance in identifying advisor performance; that is, we identify financial advisor performance with their fixed effects contribution to business performance.

In the study that is closest to ours, Bao and Edmans (2011) used the same fixed effects method to identify advisor contribution in mergers and acquisitions. They find that significant differences in advisor contribution and that these differences tend to persist. The persistence, they argue, suggests that there is some inefficiency; if business clients chased better performance, this should erode persistence (as it appears to in the retail mutual funds market). But they do not directly examine whether business switching decisions are influenced by these measures of performance. This paper considers this in relation to the fixed effects measure of general advisor performance. We then examine whether businesses encourage efficiency when they switch advisors in response to advisor performance; that is, there is a shift away from poor advisors to good advisors.

We introduce our data on advisor choice in the next section and explain how we construct measures of advisor performance in Section 3. The data on advisor choice comes from company reports. Our approach to the construction of measures of perceived advisor performance is deliberately eclectic. We generate a range of possible measures of performance to guard against a dependency on a particular and possibly questionable measure of perceived performance. We do this through plausible variation along three dimensions. First, since there are a variety of possible measures of company performance, we construct several measures of advisor performance using the Bertrand and Shoar method: one for each possible measure of company performance. Second, we allow for the possibility that companies can judge an advisor's contribution either using its contribution to absolute company performance or, possibly as a result of reference dependence, by its contribution to the change in company performance. Finally, we consider several possible connections between actual advisor performance and expected or perceived performance: expectations can be formed adaptively, rationally, or using a simple heuristic.

Section 4 considers whether advisor switching is sensitive to these measures of advisor performance. In this analysis, we allow for other possible influences on this choice. For example, own firm performance may matter both because this can lead firms to change a variety of things and because it would produce a change in advisor when matching models best explain advisor choice (see Fernando et al., 2005). Likewise, the number of other firms using a particular advisor may affect its perceived desirability. This is not only for the reasons outlined in Asker and Ljunquist (2010) over information leakage, but also because there are arguments that social influences, like herding, can play a role in the assessment of advice and opinion with the result that private information is inadequately weighted (see DeMarzo et al., 2003). There is also some experimental evidence that the willingness to pay for advice is distorted by a bias in favour of the advice from those who are similar and that excessive weight is given to this type of advice when weighing difficult decisions (see Nyarko et al., 2006; and Gino and Moore, 2007).

Section 5 discusses the results. We find that there are significant differences in our measures of advisor fixed effects and these differences in measures of advisor performance persist over time. There is also some evidence that advisor separations are related to advisor performance when we employ the simple heuristic for generating expectations. In addition, it seems the number of clients that an advisor has also affects (negatively) the probability of switching. This may be for sociological or economic reasons. There is 
some evidence to support the latter interpretation because it seems that future advisor performance is positively associated with the current number of clients. However, it is difficult to reconcile this interpretation with the evidence on the advisors that companies switch to. There is no evidence that they shift to advisors with a larger number of clients, which is what would be expected if firms understood the economic relationship between current numbers of clients and future advisor performance. Indeed, it seems that firms have difficulty anticipating the quality of their new advisor when they switch. Ditching an old advisor and hiring a new one actually only improves the quality of a company's advisor in under $10 \%$ of all separations in our sample. Section 6 concludes.

\section{DATA ON THE EMPLOYMENT OF ADVISORS AND THEIR PERFORMANCE}

Our data come from two sources. The financial data are drawn from the Extel Financial database. It is a comprehensive database that contains key financial reporting information across a large number countries and industries. Our initial sample covers about 5,000 UK listed companies from 1998 to 2008 . The data on the employment of advisors are hand-collected from Corporate Register books that contain basic information about companies, including market capitalization, ownership, information about management, banks, and advising companies. This information has been self-reported by companies. Unfortunately, the publisher of Corporate Register changed several times over the 11-year span and the list of companies is not consistent. While both database providers claim to cover the population of listed companies, there is less than $50 \%$ overlap for firms. Nevertheless, we manage to link about 2,000 advisor observations with financial information on the companies they advise.

Then we apply several selection criteria. First, we exclude companies with three or fewer observations. Second, we exclude financial advisors if the number of linked companies is less than 10 per year because this might reduce noise in measuring the fixed effects. Third, occasionally firms report more than one affiliated advisor and we have omitted these companies. Finally, to diminish the potential problem with outliers, we classify as missing the top and bottom $1 \%$ of all firm-specific indicators. As our dataset is heavily unbalanced, our estimation sample contains about 5,900 firm-years pertaining to 1,145 firms. We believe the substantial reduction of the estimation sample is entirely due to the unavailability data and can be considered exogenous.

Table B1 (in Appendix B) summarizes the variables used in the analysis and provides descriptive statistics.

\section{ADVISOR EFFECTS}

To identify the relative contribution of different advisors to firm performance in any year, we follow Bao and Edmans (2011) in adapting the Bertrand and Shoar (2003) method for estimating individual managers' influence on firm policies and performance. We estimate a fixed effects contribution that an advisor makes to the performance (or change in performance) of the firms it advises in a given year, having controlled for other determinants of firm success. For this purpose, our controls for the other possible determinants of firm performance are a vector $X_{i, t-1}$ that includes lagged values

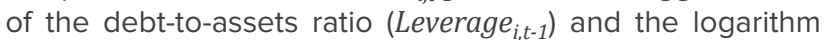
of total assets $\left(\log (T A)_{i, t-1}\right)$ as explanatory variables in the regression. These are commonly treated as determinants of firm performance (e.g. see Mehran, 1995). This company information is also readily available to market participants and, since we are interested in the perceived contribution of advisors, this procedure may plausibly capture how market participants form these kinds of judgements.

Since there are a variety of possible measures of firm performance and we have no obvious reason to prefer one over another, we use five measures of firm performance: return on equity $(R O E)$, return on assets $(R O A)$, return on sales (ROS), operating profit to total assets ratio, and Tobin's $\mathrm{Q}$. For similar reasons of inclusivity, we also allow for two possible measures of advisor contribution: their contribution to the absolute performance of the firm they advise and their contribution to the change in the performance of their firms, as in (1) and (2) below. This is because it can be argued that the judgements about performance are liable to be reference-dependent (in the sense of Kahneman, 2013) with the result that changes matter more than absolute levels.

$$
\text { Performance }_{i t}=\alpha_{1}+\Omega_{\mathrm{it}} \beta+X_{i, t-1} \delta_{1}+\epsilon_{1 t i}
$$

$$
\Delta \text { Performance }_{i t}=\alpha_{2}+\Omega_{\mathrm{it}} \gamma+X_{i, t-1} \delta_{2}+\epsilon_{2 i} .
$$

In specification (1), the fixed effect is a measure of the advisor's contribution to its firms' performances in that year. We call this Measure 1. In the second specification, the fixed effect is a measure of the advisor's contribution to its firms' change in performance in that year. We call this Measure 2. To avoid collinearity, we restrict: $\sum^{A} \beta_{a t}=\sum^{A} \gamma_{a t}=0$, so that $\beta_{a t}$ and $\gamma_{a t}$ measure advisor's a fixed effect at year $t$ as deviations from the average. Both sets of year-by-year cross-sectional regressions are estimated by OLS with robust standard errors.

Table B2 (in Appendix B) shows the estimates of specifications (1) and (2). Each row reports estimates from a cross-sectional regression for a given year in the 1998-2008 range. Column (2) and (3) report adjusted $\mathrm{R}^{2}$ with advisors' fixed effects and F-tests for the joint significance of advisors' fixed effects. In addition, we also report a benchmark specification, without any advisors' effects, in column (1). There are five panels in Table B2 that correspond to the five performance variables, namely ROA, ROE, operating income over total assets, ROS, and Tobin's Q.

Overall, Table 2 suggests that advisor fixed effects are important. They are typically statistically significant whichever of the five financial measures is used (i.e. in all 5 panels) and in both the absolute level of and change in performance equations. Notably, we have achieved improvements in goodness of fit for the majority of cross-sectional estimates. Also, the F-test $p$-values from test of joint significance are small and allow us to reject the null that advisor's fixed effects are zero in 103 out of 110 regressions. The size of the fixed effect coefficients would also appear to be economically significant. To see this, we plot in Figure A1 (in Appendix A) the difference in company performance associated with having an advisor in the top quartile as compared with one in the bottom quartile in each year. In every year, this difference is as big as the mean performance of companies in that year. 
We now test for whether these identified measures of advisor performance are random variables by considering whether they can be described by an autoregressive process. In these regressions, we allow for the possibility that the current number of company advisees as well as the current performance of the advisor might help predict the future performance of that advisor. These regressions are set out in Table B3 (in Appendix B).

It is apparent from these regressions that both Measure 1 and Measure 2 are not random variables: i.e. it is not just the throw of a dice and knowing current advisor performance would be useful in predicting future performance for both measures. We also note that the number of companies served is also typically a useful predictor of advisor performance.

The autoregressive structure of our advisor performance measure is important. It means that a simple adaptive expectation mechanism of projecting current own advisor performance into the future would be better than assuming that own advisor's future performance was a random draw. For this reason, we use previous own advisor performance to predict own current advisor performance under adaptive expectations in the next section.

We also consider the possibility that companies use a simple rule of thumb to judge their advisors. Given the difficulty of judging advisor quality, and the evidence that people often use simple behavioural rules in these circumstances, this is not implausible. One such rule first distinguishes advisors broadly according to whether advisors are above or below average in any year and then judges advisor quality in the following way: advisors are deemed "good" if they have been above average for the last two years, "bad" if they have been below average for the last two years, and "neutral" if they flip-flop between the two. This is, of course, plausible. The virtue of this approach is that it recognises, albeit imperfectly, i) that companies may appreciate broad differences between advisors but not the fine-grained differences generated by our fixed effects; and ii) that, given the random element in performance, only persistence in advisor performance is useful. We call these "simpler" measures of perceived advisor performance SMeasure1 and SMeasure2. Table B4 (in Appendix B) provides the distribution of advisors according to this simpler measure of performance.

\section{DETERMINANTS OF ADVISOR SWITCHING AND ITS EFFECTS ON ADVISOR QUALITY}

In this section, we distinguish two decisions: i) whether to change an advisor and; ii) if a separation occurs, the new hiring decision; and we consider what factors appear to affect each decision. We are especially concerned with whether advisor performance plays a role in these decisions such that they promote efficiency in the market for business financial advice.

Towards this end, and following the discussion at the end of the last section, we consider first whether the probability that a firm $i$ changes its advisor in the current period is affected by the performance of its advisor in the previous period (for advisor $j=\beta_{j, t-1}$ for Measure 1 and $\gamma_{j, t-1}$ for Measure 2). In addition to the performance of advisors, we have the lagged performance of the firm itself (Performance ${ }_{i, t-1}$ ) as a possible determinant of the switching decision and the number of other firms that use the same advisor in the previous period $\left(N_{j, t-1}\right)$, and we also have firm size measure by the lagged natural logarithm of total assets, $\log (T A)_{i, t-1}$. Thus, we estimate versions of equations (3) and (4).

$$
\begin{aligned}
& \operatorname{Prob}\left(\text { Switch }_{i t}=1\right)=\Lambda\left(\alpha_{3}+v_{3} \text { Performance }_{i, t-1}\right. \\
& \left.+\mu_{3} \hat{\beta}_{j, t-1}+\eta_{3} N_{j, t-1}+\omega_{3} \log (T A)_{i, t-1}+\epsilon_{3 i}\right), \\
& \operatorname{Prob}\left(\text { Switch }_{i t}=1\right)=\Lambda\left(\alpha_{4}+v_{4} \text { Performance }_{i, t-1}\right. \\
& \left.+\mu_{4} \hat{\gamma}_{j, t-1}+\eta_{4} N_{j, t-1}+\omega_{4} \log (T A)_{i, t-1}+\epsilon_{4 i}\right) .
\end{aligned}
$$

Equations (5) and (6) substitute the simpler measures of advisor performance in these equations: that is, instead of $\beta_{j, t-1}$ and $\gamma_{j, t-1}$, we have dummies that take on a value of 1 when the advisor was either "good" or "bad" in the previous time period based respectively on $\beta_{j, t-1}$ and $\gamma_{j, t-1}$.

$$
\begin{aligned}
& \operatorname{Prob}\left(\text { Switch }_{i t}=1\right)=\Lambda\left(\alpha_{5}+v_{5} \text { Performance }_{i, t-1}+\right. \\
& +\mu_{5} G O O D^{\widehat{\beta}}{ }_{j, t-1}+\zeta_{5} B A D^{\widehat{\beta}}{ }_{j, t-1}+\eta_{5} N_{j, t-1}+ \\
& \left.+\omega_{5} \log (T A)_{i, t-1}+\epsilon_{5 i}\right) \text {, } \\
& \operatorname{Prob}\left(\text { Switch }_{i t}=1\right)=\Lambda\left(\alpha_{6}+v_{6} \text { Performance }_{i, t-1}+\right. \\
& +\mu_{6} G O O D_{j, t-1}^{\widehat{\gamma}_{j}}+\zeta_{6} B A D_{j, t-1}^{\widehat{\gamma}_{j}}+\eta_{6} N_{j, t-1}+ \\
& \left.+\omega_{6} \log (T A)_{i, t-1}+\epsilon_{6 i}\right) \text {. }
\end{aligned}
$$

Table B5 (in Appendix B) provides the results of equations 3 (panel A) and 5 (panel B): i.e. those based on Measure 1 and SMeasure1. Each column refers to one of the 5 ways of measuring firm financial performance. Table B6 (in Appendix B) shows the results of equations 4 (panel A) and 6 (panel B): i.e. those based on Measure 2 and SMeasure 2.

It is apparent from these tables that advisor performance is only significant in determining the probability of switching in equation 5 (i.e. when we use SMeasure 1). In particular, the only indicator of advisor performance that affects the probability of switching (negatively) is whether the advisor was deemed "good" under our simple rule in the previous period because it had performed above average in the previous two years. So firms tend to hold on to a "good" advisor but they are no more likely to separate from a "bad" advisor than a "neutral" advisor. Own firm performance weakly tends to affect the probability of switching (the better the performance in the past, the less likely a switch). Finally, the number of clients an advisor has also always seems to reduce the likelihood of a switch.

We turn now to the decision over new advisors when there has been a separation. Since we have found that the simple heuristic measure of advisor performance seems to influence the separation decision, we focus on this measure of advisor performance in what follows. We examine in Panel A of Table B7 (in Appendix B) whether a change leads to an improvement in their advisor's performance and whether this change is different to what would be expected if the choice of new advisor was random (given the distribution of advisors between these types given in Table B4). 
We find no evidence here that the firms' new choice of advisor is any more likely to improve advisor quality than that which would be expected from chance and there is a considerable number of these choices that in practice have no effect on advisor performance (i.e. it remains in the same category as before). Perhaps not unsurprisingly in view of this result, there is also no evidence that a switch tends to shift a firm to a more popular advisor.

Finally, we report in Panel B of Table B7 on whether as a group those companies that switch perform better in the period of the switch than those that do not. It seems they do not.

\section{DISCUSSION}

Advisor quality is not easily observable. This is a problem for companies, and as a result, it is also a problem for any research concerned with whether company advisor decisions promote efficiency in the advising market. We have tackled this problem by generating a variety of possible measures of advisor performance. There are, in effect, two sets of measures. One is fine-grained and assumes that companies can make use of relevant information on a range of indicators of company performance to extract the contribution made by advisors. The other assumes that companies can only make coarse judgements about whether an advisor is above or below average in any one year and they use simple rules of thumb to project from these judgments to the underlying quality of an advisor. With both types of measures, we allow for judgments to be based on the absolute performance of the company and, to allow for the possibility that these judgments may be reference dependent, to be based on the change in company performance. Of course, all these measures depend on the strategy of using fixed effects to capture the contribution of advisors to firm performance. This has been used in other contexts. Nevertheless, it may fail. There could be omitted variables that explain both company performance and their choice of advisor. In defence of the strategy, we have included the variables that are standard in company performance equations.

We find no evidence that a company's decision to change an advisor is related to any of our fine-grained, fixed effect measures of expected advisor performance. This conclusion holds whether we assume companies form expectations adaptively or rationally or whether they focus on advisor contribution to absolute company performance or changes in company performance. However, we do find evidence that if companies use a simple rule of thumb to judge advisor performance, then the decision to separate is influenced by this measure of expected performance. This is so in all the regressions where advisor performance is based on this rule when applied to absolute company performance. Given the difficulties of disentangling the influence of an advisor from the range of other factors affecting company performance, it would not be surprising if companies had recourse to such a simple rule of thumb. Of course, there are many such rules but ours has the virtue of a broad distinction between whether advisors are above or below average in any year and it has a simple way of projecting from annual performance that is subject to randomness to an assessment of underlying quality.

If the evidence on rule of thumb measures is accepted, then it seems that company separation decisions do promote efficiency, albeit only weakly. These decisions promote efficiency because we find evidence that if an advisor is judged using this rule to be "good", then the company is less likely to separate. Having a bad advisor, though, does not increase the chances of separation. So the separation decision tends to promote efficiency on this measure, but only weakly as there is no apparent distinction between "bad" and "neutral" advisors. This contrasts with the evidence on the company choice of underwriters, which seem unrelated to success in underwriting (e.g. Asker and Ljunquist, 2010; and Krigman et al., 2001). It is possible that our stronger result in this respect arises because we use a general measure of advisor performance (rather than the narrower one of underwriting success) and companies select an advisor for a range of tasks and so are concerned with more general measures of performance (as suggested by Krigman et al., 2001).

Whether we use the fine-grained measures or the rules of thumb for gauging advisor performance, we always find that the number of clients an advisor has reduces the probability of a separation. This is, therefore, a robust feature of our data set. That association may arise for sociological/ psychological or economic reasons. Business leaders might assume, for example, that so long as an advisor is used widely by others in their social network, the advisor is acceptable. Numbers provides a kind of cognitive reassurance that there is nothing to worry about. Alternatively, since we find that the current number of clients actually helps predict future advisor performance, companies might appreciate this and for economic reasons be less inclined to maintain an advisor with few clients. The positive influence of client numbers on future performance suggests economies of scale. These may plausibly arise since the acquisition of knowledge on the economy and the financial sector that is a key cost in the provision of financial advice is largely a fixed cost.

However, in light of our evidence on new hires, this economic interpretation of the sensitivity of separation to client numbers is difficult to maintain. There is no evidence that companies move to advisors with a larger number of clients as would be expected if companies understood the role of client numbers in influencing advisor performance. There is, however, a simple explanation of how this case might arise (for both the economic and the social/ psychological explanations). In so far as knowledge of client numbers is largely drawn from the events that are organised by advisors for the benefit of their clients, then this builds in such an asymmetry. Advisors frequently organise or sponsor business and sporting events to which they invite their clients. Attendance at such events gives clients an immediate impression of the number of fellow clients who employ their advisor, but, of course, it offers no information on the number of clients at other advisors. In these circumstances, it would not be surprising, as we find, that the choice of a new advisor is much like a random draw from the advisor pool.

This fits with our final finding. When companies switch, they do not significantly improve advisor quality on any measure of advisor performance. This may seem a little surprising given the sensitivity of the separation decision to advisor performance when judged by the rule of thumb. But, again, if knowledge of advisor quality depends largely on that company's experience (i.e. it is largely local, for reasons that now include advisor-based social networks), then they will be much better informed about the quality of their current advisor than any prospective one. 
One way of putting these results into perspective is to consider the proportion of switches that improve advisor performance judged by the rule of thumb measure. In our sample there are 459 switches (12.5\% of the sample). The number of companies at good advisors increases by 43 , but the number of companies at poor advisors also increases, albeit by a smaller number of 12 . The net number of improvers (31) is less than $7 \%$ of all switches. In the aggregate, therefore, if switches are to improve performance when there are costs from switching, then the benefits from a switch will have to be about 12 times whatever the typical cost of a switch. This seems like a large net benefit and so perhaps it is not surprising that companies that switch do not on average seem to perform better than those that do not.

\section{CONCLUSIONS}

Markets depend for their efficiency on consumers switching from poor performing producers to better performing ones. We study whether this happens in the market for financial advisory services to businesses. The market is an interesting case study because there appear to be significant differences in advisor performance. That these differences persist to some degree over time suggests that whatever switching behaviour does occur, it does not erode all opportunities for gain. In fact, even though we use a large number of potential measures of advisor performance, we find only weak evidence that company separation and re-hiring decisions for their advisors are influenced by any measure of advisor performance. It is weak in two respects. First, there is no evidence that these decisions are sensitive to our fine-grained fixed effects measure of advisor performance. Second. while there is evidence that a rule of thumb judgment of advisor performance affects the separation decision in the sense that firms tend to retain "good" advisors on this measure (but don't distinguish between "bad" and "neutral" ones), there is no evidence that performance on this or any measure influences new hiring decisions.
As a result, we find that, using this rule of thumb measure, on balance only $7 \%$ of all switches yield an improvement in advisor quality. In short, there is a substantial amount of switching with no benefit.

These are important results. First, they may help explain the growth in payments to advisors. Denton (1985) supplies one model of how this might arise when advisor quality is difficult to disentangle from luck. But, in general, it is not surprising that the market value of advisor services should at times appear to defy gravity if, as we find, business consumers of those services appear to have such little appreciation of their value.

Second, it provokes an obvious question about what explains company behaviour if they are responding only weakly to differences in the quality of advisors. There is one robust feature of our data set that may provide an insight into this question. The number of clients seems to reduce the likelihood of a company separating, but it does not affect the choice of new advisor. The effect on separation decisions is consistent with either a socio/ psychological herd-like explanation or an economic one because there is evidence that client numbers help predict future advisor performance. But the lack of an effect on new hire decisions is difficult to understand on either account. This asymmetry might, however, be explained by the fact that advisors often invite their clients to social and business events. This gives companies an idea about how many other clients their advisor has, but, of course, it provides no information on the number of clients at other advisors. If client numbers are regarded as a signal of quality for whatever reason and this is the major source of information on these numbers, then this would explain how these numbers affect separation decisions but not newhire ones. 


\section{REFERENCES}

- Andres C., Betzer A., Limbach P. (2014). Underwrite Reputation and the Quality of Certification: Evidence From High Yield Bonds. Journal of Banking and Finance, Vol. 40, No. C, pp 97-115. https://doi.org/10.1016/j.jbankfin.2013.11.029

Arrow K. J. (1963). Uncertainty and the Welfare Economics of Medical Care. American Economic Review, Vol. 53, No. 5, pp. 941-973.

- Asker J., Ljungqvist A. (2010). Competition and the Structure of Vertical Relationships in Capital Markets. Journal of Political Economy, Vol. 118, No, 3, pp. 599-647. https://doi.org/10.1086/653452

- Baccara M. (2007). Outsourcing, Information Leakage, and Consulting Firms. RAND Journal of Economics, Vol. 38, No. 1, pp. 269-289. https://doi.org/10.1111/j.1756-2171.2007.tb00055.x

Balafotas L., Kocher M., Putterman L., Sutter M. (2013). Equality, Equity and Incentives: An Experiment. European Economic Review, Vol. 60, pp. 32-51. https://doi.org/10.1016/j.euroecorev.2013.01.005

- Bao J., Edmans A. (2011). Do Investment Banks Matter for M\&A Returns? Review of Financial Studies, Vol. 24, No. 7, pp. 2286-2315. https://doi.org/10.1093/rfs/hhr014

- Benveniste L. M., Busaba W.Y., Wilhelm W. J. Jr. (2002). Information Externalities and the Role of Underwriters in Primary Equity Markets. Journal of Financial Intermediation, Vol. 11, No. 1, pp. 61-86. https://doi.org/10.1006/jfin.2000.0310

- Benveniste L. M., Ljungqvist A., Wilhelm W. J., Yu X. (2003). Evidence of Information Spillovers in the Production of Investment Banking Services. Journal of Finance, Vol. 58, No. 2, pp. 577-608. https://doi.org/10.1111/1540-6261.00538

- Benveniste L. M., Spindt P. A. (1989). How Investment Bankers Determine the Offer Price and Allocation of New Issues. Journal of Financial Economics, Vol. 24, No. 2, pp. 343-361. https://doi.org/10.1016/0304-405X(89)90051-2

Bertrand M., Schoar A. (2003). Managing with Style: The Effect of Managers on Firm Policies. Quarterly Journal of Economics, Vol. 118, No. 4, pp. 1169-208. https://doi.org/10.1162/003355303322552775

- Booth J. R., Smith R. (1986). Capital Raising, Underwriting and the Certification Hypothesis, Journal of Financial Economics, Vol. 15, No. 1-2, pp. 261-281. https://doi.org/10.1016/0304-405X(86)90057-7

- Chemmanur T., Krishnan K. (2012). Heterogeneous Beliefs, IPO Valuation, and the Economic Role of the Underwriter in IPOs. Financial Management, Vol. 41, No. 4, pp. 769-811. https://doi.org/10.1111/j.1755-053X.2012.01201.x

DeMarzo P. M., Vayanos D., Zwiebel J. (2003). Persuasion Bias, Social Influence and Uni-Dimensional Opinions. Quarterly Journal of Economics, Vol. 118, No. 3, pp. 909-968. https://doi.org/10.1162/00335530360698469
Denton F. T. (1985). The Effect of Professional Advice on the Stability of a Speculative Market. Journal of Political Economy, Vol. 93, No. 5, pp. 977-993. https://doi.org/10.1086/261345

Fang L.H. (2005). Investment Bank Reputation and the Price and Quality of Underwriting Services. Journal of Finance, Vol, 60, No. 6, pp. 2729-2761. https://doi.org/10.1111/j.1540-6261.2005.00815.x

Fernando C. S., Gatchev V. A., Spindt P. A. (2005). Wanna Dance? How Firms and Underwriters Choose Each Other. Journal of Finance, Vol. 60, No. 5, pp. 2437-2469. https://doi.org/10.1111/j.1540-6261.2005.00804.x

- Gino F., Moore D. A. (2007). Effects of Task Difficulty on Use of Advice. Journal of Behavioral Decision Making, Vol. 20, No. 1, pp. 21-35. https://doi.org/10.1002/bdm.539

- Giulietti M., Price C. W., Waterson M. (2005). Consumer Choice and Competition Policy: a Study of UK Energy Markets. Economic Journal, Vol. 115, No. 506, pp. 949-968. https://doi.org/10.1111/j.1468-0297.2005.01026.x

- Kale J. R., Kini O., Ryan H. (2003). Financial Advisors and Shareholder Wealth Gains in Corporate Takeovers. Journal of Financial and Quantiative Analysis, Vol. 38, No. 3, pp. 478-501.

- Krigman L., Shaw W. H., Womack K. L. (2001). Why do Firms Switch Underwriters? Journal of Financial Economics, Vol. 60, No. 2-3, pp. 245-284. https://doi.org/10.1016/S0304-405X(01)00045-9

- Logue D. (1973). On the Pricing of Unseasoned Equity Issues:1965-1969. Journal of Financial and Quatitative Analysis. Vol. 8, No. 1, pp. 91-103. https://doi.org/10.2307/2329751

- Mehran H. (1995). Executive Compensation Structure, Ownership, and Firm Performance. Journal of Financial Economics, Vol. 38, No. 2, pp. 163-184. https://doi.org/10.1016/0304-405X(94)00809-F

- Michel M., Shaked I., Lee Y. (1991). An Evaluation of Investment Banker Acquisition Advice: the Shareholder Perspective. Financial Management, Vol. 20, pp. 40-49.

- Neuberger B., Hammond C. (1974). A Study of Underwriters' Experience With Unseasoned New Issues. Journal of Financial and Quantitative Analysis, Vol. 9, No. 02, pp. 165-177.

- Nyarko Y., Schotter A., Sopher B. (2006). On the Informational Content of Advice: A Theoretical and Experimental Study. Economic Theory, Vol. 29. No. 2, pp. 433-452. https://doi.org/10.1007/s00199-005-0037-7

- Waddams C., Zhu M. (2016). Empirical Evidence of Consumer Response in Regulated Markets. Journal of Competition Law and Economics. Vol. 12, No. 1, pp. 113-149. https://doi.org/10.1093/joclec/nhv041 


\section{APPENDIX A. FIGURE}

Figure A1. Average Performance and Quartiles of Advisors' Fixed Effects $(\hat{\beta}$ and $\hat{\gamma})$

Panel A: Levels
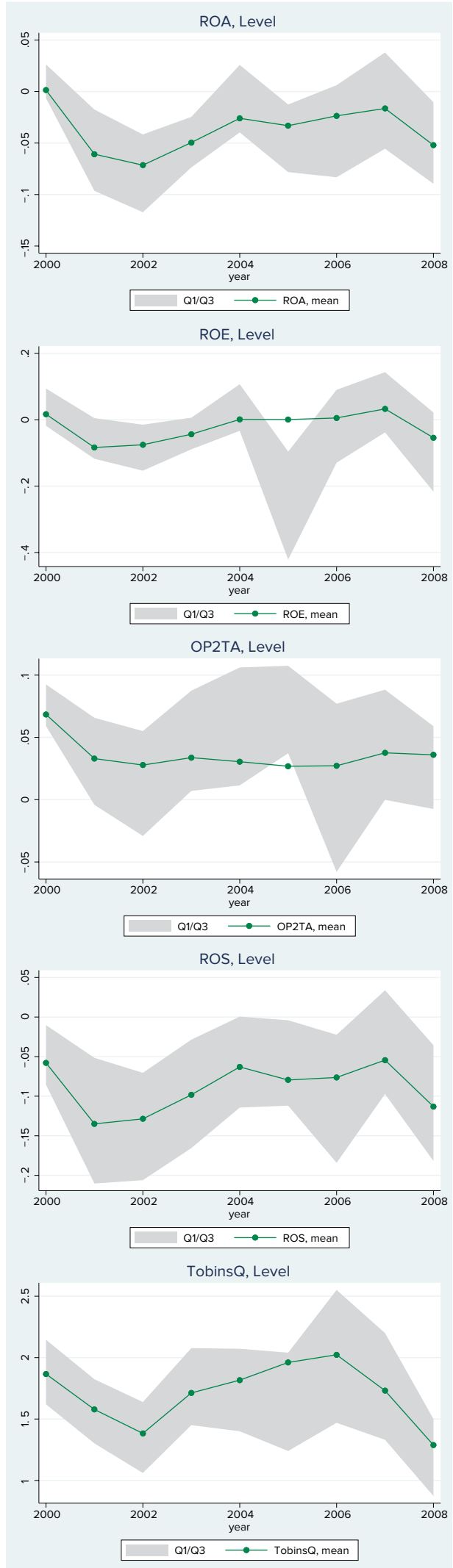

\section{Panel B: Differences}
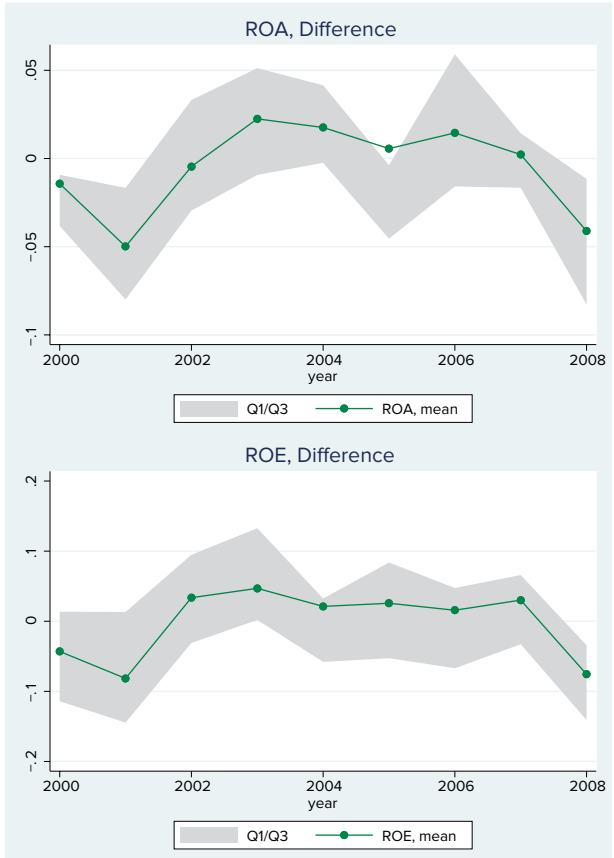

OP2TA, Difference

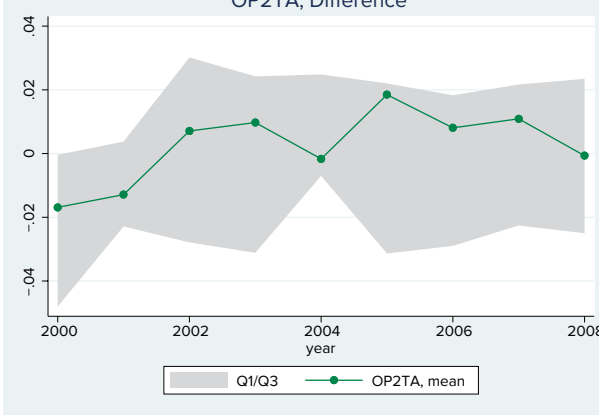

ROS, Difference

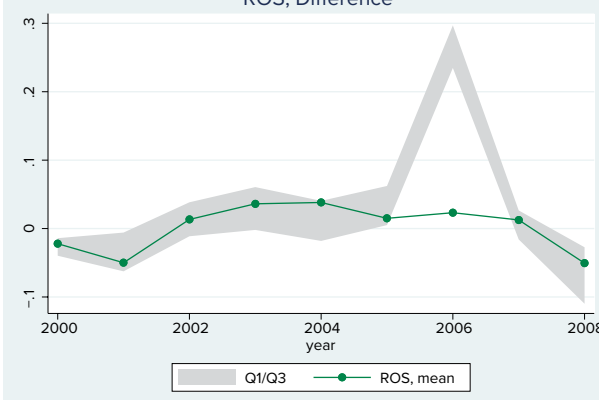

TobinsQ, Difference

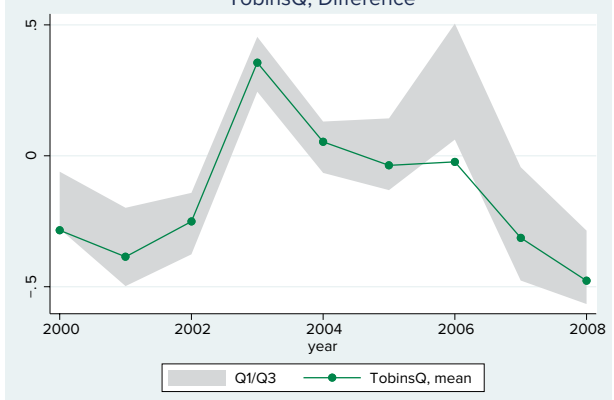

Notes: The figures plot average, first quartile and third quartile advisor performance. Panel A measures are based on levels of firm performance, while Panel B measures are based on differences in firm performance. The study uses five measures of performance, namely ROA, ROE, Operating Income/Total Assets, ROS, and Tobin's $Q$. 
APPENDIX B. TABLES

Table B1. Descriptive Statistics

\begin{tabular}{|c|c|c|c|c|c|c|}
\hline Variable & $\begin{array}{c}\text { Mean } \\
\text { (1) }\end{array}$ & $\begin{array}{c}\text { Standard } \\
\text { Deviation } \\
\text { (2) }\end{array}$ & $\begin{array}{l}\text { Q1 } \\
\text { (3) }\end{array}$ & $\begin{array}{l}\text { Q2 } \\
\text { (4) }\end{array}$ & $\begin{array}{l}\text { Q3 } \\
\text { (5) }\end{array}$ & $\begin{array}{l}N \\
\text { (6) }\end{array}$ \\
\hline ROA (level) & 0.00 & 0.17 & -0.03 & 0.05 & 0.10 & 3,612 \\
\hline ROE (level) & 0.01 & 0.38 & -0.06 & 0.08 & 0.18 & 3,612 \\
\hline OP/TA (level) & 0.07 & 0.16 & 0.03 & 0.09 & 0.15 & 3,612 \\
\hline ROS (level) & -0.04 & 0.28 & -0.03 & 0.04 & 0.09 & 3,612 \\
\hline Tobins Q (level) & 1.61 & 0.99 & 0.99 & 1.27 & 1.81 & 3,612 \\
\hline ROA (diff) & -0.01 & 0.14 & -0.04 & -0.00 & 0.03 & 3,612 \\
\hline ROE (diff) & -0.00 & 0.40 & -0.09 & -0.00 & 0.06 & 3,612 \\
\hline OP/TA (diff) & 0.00 & 0.11 & -0.04 & 0.00 & 0.04 & 3,612 \\
\hline ROS (diff) & -0.00 & 0.20 & -0.03 & 0.00 & 0.03 & 3,612 \\
\hline Tobins Q (diff) & -0.10 & 0.66 & -0.26 & -0.03 & 0.13 & 3,612 \\
\hline Leverage & 0.22 & 0.19 & 0.07 & 0.18 & 0.31 & 3,449 \\
\hline Log (Total Assets) & 18.25 & 2.01 & 16.84 & 18.13 & 19.61 & 3,612 \\
\hline Log Firms_Total & 3.31 & 0.60 & 3.04 & 3.43 & 3.74 & 3,612 \\
\hline$\hat{\beta}$ (level ROA) & 0.01 & 0.05 & -0.02 & 0.02 & 0.04 & 3,431 \\
\hline$\hat{\beta}$ (level ROE) & -0.02 & 0.15 & -0.05 & 0.01 & 0.07 & 3,431 \\
\hline$\hat{\beta}($ level OP/TA) & 0.01 & 0.05 & -0.01 & 0.02 & 0.04 & 3,431 \\
\hline$\hat{\beta}$ (level ROS) & 0.02 & 0.08 & -0.03 & 0.03 & 0.07 & 3,431 \\
\hline$\hat{\beta}$ (level Tobins Q) & -0.03 & 0.45 & -0.32 & -0.08 & 0.25 & 3,431 \\
\hline$\hat{\gamma}(\operatorname{diff} \mathrm{ROA})$ & 0.00 & 0.04 & -0.02 & 0.00 & 0.02 & 3,431 \\
\hline$\hat{\gamma}$ (diff ROE) & 0.01 & 0.11 & -0.06 & 0.01 & 0.06 & 3,431 \\
\hline$\hat{\gamma}($ diff OP/TA) & -0.01 & 0.03 & -0.02 & -0.00 & 0.01 & 3,431 \\
\hline$\hat{\gamma}$ (diff ROS) & -0.00 & 0.06 & -0.03 & 0.00 & 0.03 & 3,431 \\
\hline$\hat{\gamma}$ (diff Tobins Q) & 0.02 & 0.20 & -0.08 & 0.02 & 0.14 & 3,431 \\
\hline
\end{tabular}

Notes: Advisor performance measures are $\hat{\beta} \mathrm{s}$, fixed effects based on level performance equation, and $\hat{\gamma}$, fixed effects based on different performance equations. Q1, Q2, Q3 correspond to the first, second, and third quartiles of distribution, respectively. $\mathrm{N}$ is the number of observations. 
Table B2. Significance of an Advisor's Fixed Effects

Panel A: ROA

\begin{tabular}{|c|c|c|c|c|c|c|}
\hline & \multicolumn{3}{|c|}{ Levels } & \multicolumn{3}{|c|}{ Differences } \\
\hline & $\begin{array}{c}\text { Adj R2 } \\
\text { (1) }\end{array}$ & $\begin{array}{c}\text { Adj R2 } \\
\text { (2) }\end{array}$ & $\begin{array}{c}F(p v a l) \\
(3)\end{array}$ & $\begin{array}{c}\text { Adj R2 } \\
\text { (1) }\end{array}$ & $\begin{array}{c}\text { Adj R2 } \\
\text { (2) }\end{array}$ & $\begin{array}{c}\text { F (pval) } \\
\text { (3) }\end{array}$ \\
\hline 1999 & -0.01 & 0.08 & 0.00 & 0.03 & 0.05 & 0.00 \\
\hline 2000 & 0.05 & 0.07 & 0.16 & -0.00 & -0.02 & 0.60 \\
\hline 2001 & 0.10 & 0.09 & 0.00 & 0.03 & 0.04 & 0.00 \\
\hline 2002 & 0.12 & 0.17 & 0.00 & 0.01 & 0.02 & 0.00 \\
\hline 2003 & 0.15 & 0.13 & 0.00 & 0.03 & 0.01 & 0.00 \\
\hline 2004 & 0.19 & 0.19 & 0.00 & 0.00 & 0.04 & 0.00 \\
\hline 2005 & 0.22 & 0.24 & 0.00 & 0.01 & -0.01 & 0.00 \\
\hline 2006 & 0.13 & 0.13 & 0.00 & 0.01 & 0.00 & 0.01 \\
\hline 2007 & 0.15 & 0.16 & 0.00 & 0.02 & 0.05 & 0.00 \\
\hline 2008 & 0.06 & 0.07 & 0.00 & 0.03 & 0.06 & 0.00 \\
\hline
\end{tabular}

Panel B: ROE

\begin{tabular}{lcccccc}
\hline & Adj R2 & Levels & Adj R2 & F (pval) & Adj R2 & Differences \\
& $\mathbf{( 1 )}$ & $\mathbf{( 2 )}$ & $\mathbf{( 3 )}$ & $\mathbf{( 1 )}$ & $\mathbf{( 2 )}$ & $\mathbf{F}$ (pval) \\
\hline 1999 & 0.01 & 0.06 & 0.00 & 0.06 & 0.10 & 0.00 \\
2000 & 0.02 & 0.04 & 0.29 & -0.00 & 0.01 & 0.12 \\
2001 & 0.01 & 0.01 & 0.00 & -0.00 & -0.02 & 0.00 \\
2002 & 0.03 & 0.03 & 0.00 & 0.00 & 0.01 & 0.00 \\
2003 & 0.03 & -0.00 & 0.00 & 0.02 & 0.01 & 0.00 \\
2004 & 0.07 & 0.05 & 0.00 & 0.05 & 0.04 & 0.00 \\
2005 & 0.11 & 0.16 & 0.00 & 0.00 & 0.02 & 0.00 \\
2006 & 0.11 & 0.12 & 0.00 & -0.00 & -0.05 & 0.00 \\
2007 & 0.06 & 0.04 & 0.00 & 0.04 & -0.00 & 0.00 \\
2008 & 0.03 & 0.03 & 0.00 & 0.01 & 0.01 & 0.00 \\
\hline
\end{tabular}

Panel C: Operating Income / TA

\begin{tabular}{lcccccc}
\hline & Adj R2 & Levels & Adj R2 & F (pval) & Adj R2 & Differences \\
& $\mathbf{( 1 )}$ & $\mathbf{( 2 )}$ & $\mathbf{( 3 )}$ & $\mathbf{( 1 )}$ & $\mathbf{( 2 )}$ & F2 \\
\hline 1999 & 0.02 & 0.01 & 0.24 & 0.02 & 0.03 & 0.39 \\
2000 & 0.04 & 0.05 & 0.00 & 0.00 & 0.04 & 0.00 \\
2001 & 0.16 & 0.15 & 0.00 & 0.03 & 0.03 & 0.00 \\
2002 & 0.17 & 0.23 & 0.00 & 0.00 & 0.04 & 0.00 \\
2003 & 0.19 & 0.20 & 0.00 & 0.02 & 0.05 & 0.00 \\
2004 & 0.19 & 0.21 & 0.00 & 0.01 & 0.02 & 0.00 \\
2005 & 0.13 & 0.12 & 0.00 & 0.07 & 0.06 & 0.00 \\
2006 & 0.15 & 0.18 & 0.00 & -0.00 & -0.04 & 0.00 \\
2007 & 0.15 & 0.14 & 0.00 & 0.04 & 0.03 & 0.00 \\
2008 & 0.11 & 0.12 & 0.00 & 0.05 & 0.02 & 0.00 \\
\hline
\end{tabular}


Table B2 continued

Panel D: ROS

\begin{tabular}{lcccccc}
\hline & Adj R2 & Levels & Adj R2 & F (pval) & Adj R2 & Differences \\
& $\mathbf{( 1 )}$ & $\mathbf{( 2 )}$ & $\mathbf{( 3 )}$ & $\mathbf{( 1 )}$ & $\mathbf{( 2 )}$ & $\mathbf{F}$ (pval) \\
& 0.01 & 0.07 & 0.00 & 0.03 & 0.05 & 0.00 \\
\hline 1999 & 0.05 & 0.06 & 0.13 & -0.00 & -0.04 & 0.95 \\
2000 & 0.10 & 0.10 & 0.00 & 0.01 & 0.00 & 0.00 \\
2001 & 0.13 & 0.14 & 0.00 & -0.00 & 0.02 & 0.05 \\
2002 & 0.12 & 0.12 & 0.00 & 0.05 & 0.02 & 0.27 \\
2003 & 0.13 & 0.12 & 0.00 & 0.01 & 0.09 & 0.01 \\
2004 & 0.16 & 0.14 & 0.00 & 0.03 & 0.03 & 0.00 \\
2005 & 0.09 & 0.09 & 0.00 & 0.01 & -0.00 & 0.00 \\
2006 & 0.13 & 0.13 & 0.00 & 0.01 & -0.02 & 0.00 \\
2007 & 0.06 & 0.05 & 0.00 & 0.02 & 0.04 & 0.15 \\
\hline
\end{tabular}

Panel E: Tobin's Q

\begin{tabular}{|c|c|c|c|c|c|c|}
\hline & \multicolumn{3}{|c|}{ Levels } & \multicolumn{3}{|c|}{ Differences } \\
\hline & $\begin{array}{c}\text { Adj R2 } \\
\text { (1) }\end{array}$ & $\begin{array}{c}\text { Adj R2 } \\
\text { (2) }\end{array}$ & $\begin{array}{c}\text { F (pval) } \\
(3)\end{array}$ & $\begin{array}{c}\text { Adj R2 } \\
\text { (1) }\end{array}$ & $\begin{array}{c}\text { Adj R2 } \\
\text { (2) }\end{array}$ & $\begin{array}{c}F \text { (pval) } \\
(3)\end{array}$ \\
\hline 1999 & 0.05 & 0.06 & 0.07 & 0.02 & 0.00 & 0.12 \\
\hline 2000 & 0.03 & 0.03 & 0.00 & 0.00 & 0.05 & 0.00 \\
\hline 2001 & 0.02 & 0.07 & 0.00 & 0.04 & 0.03 & 0.00 \\
\hline 2002 & 0.07 & 0.12 & 0.00 & 0.01 & 0.05 & 0.00 \\
\hline 2003 & 0.13 & 0.21 & 0.00 & 0.05 & 0.06 & 0.00 \\
\hline 2004 & 0.11 & 0.19 & 0.00 & -0.00 & 0.00 & 0.00 \\
\hline 2005 & 0.06 & 0.12 & 0.00 & 0.02 & 0.07 & 0.00 \\
\hline 2006 & 0.02 & 0.12 & 0.00 & 0.03 & 0.04 & 0.00 \\
\hline 2007 & 0.05 & 0.13 & 0.00 & 0.01 & 0.05 & 0.00 \\
\hline 2008 & 0.08 & 0.20 & 0.00 & -0.00 & 0.07 & 0.00 \\
\hline
\end{tabular}

Notes. Dependent variables are levels of difference of performance, based on ROA, ROE, Operating Income/TA, ROS, and Tobin's Q. Columns (1) and (2) report adjusted $R^{2}$ for the cross-sectional OLS specifications with and without an advisor's fixed effects, respectively. $F($ pval) in Column (3) is the p-value for the F-test of joint significance of an advisor's fixed effects. 


\section{Table B3. Autocorrelations}

Panel A: The Dependent Variable is the Advisor's Fixed Effects Based on Levels, $\hat{\beta}$

\begin{tabular}{|c|c|c|c|c|c|}
\hline & $\begin{array}{l}\text { ROA } \\
\text { (1) }\end{array}$ & $\begin{array}{c}\text { ROE } \\
(2)\end{array}$ & $\begin{array}{c}\text { OP/TA } \\
\text { (3) }\end{array}$ & $\begin{array}{c}\text { ROS } \\
(4)\end{array}$ & $\begin{array}{c}\text { Tobin's C } \\
\text { (5) }\end{array}$ \\
\hline \multirow[t]{2}{*}{$\hat{\beta}_{t-1}$} & $0.194^{* * *}$ & 0.017 & $0.297^{* * *}$ & $0.173^{* * *}$ & $0.174^{* * *}$ \\
\hline & $(0.025)$ & $(0.030)$ & $(0.055)$ & (0.039) & $(0.045)$ \\
\hline \multirow[t]{2}{*}{$\log (\text { Firms })_{t}$} & $0.020^{* * *}$ & $0.022^{* * *}$ & $0.030^{* * *}$ & $0.030^{* * *}$ & $-0.140^{* * *}$ \\
\hline & $(0.002)$ & $(0.002)$ & $(0.003)$ & (0.004) & $(0.037)$ \\
\hline Sargan, $p$-value & 0.801 & 0.661 & 0.030 & 0.065 & 0.001 \\
\hline $\mathrm{AR}(2), p$-value & 0.280 & 0.546 & 0.387 & 0.461 & 0.319 \\
\hline N obs. & 180 & 180 & 180 & 179 & 180 \\
\hline
\end{tabular}

Panel B: The Dependent Variable is the Advisor's Fixed Effects Based on Differences, $\hat{\gamma}$

\begin{tabular}{|c|c|c|c|c|c|}
\hline & $\begin{array}{c}\text { ROA } \\
\text { (1) }\end{array}$ & $\begin{array}{l}\text { ROE } \\
(2)\end{array}$ & $\begin{array}{c}\text { OP/TA } \\
\text { (3) }\end{array}$ & $\begin{array}{c}\text { ROS } \\
\text { (4) }\end{array}$ & $\begin{array}{c}\text { Tobin's Q } \\
\text { (5) }\end{array}$ \\
\hline \multirow[t]{2}{*}{$\hat{\gamma}_{t-1}$} & $-0.154^{* * *}$ & $-0.146^{* * *}$ & $-0.172^{* * *}$ & $-0.111^{* *}$ & $-0.167^{* * *}$ \\
\hline & (0.014) & $(0.024)$ & (0.024) & $(0.050)$ & (0.053) \\
\hline \multirow[t]{2}{*}{$\log (\text { Firms })_{t}$} & $-0.009^{* * *}$ & $0.016^{* * *}$ & $-0.020^{* * *}$ & $0.017^{* * *}$ & $0.040^{* *}$ \\
\hline & $(0.001)$ & (0.003) & (0.002) & (0.003) & $(0.018)$ \\
\hline Sargan, $p$-value & 0.345 & 0.072 & 0.011 & 0.384 & 0.010 \\
\hline AR(2), $p$-value & 0.962 & 0.124 & 0.504 & 0.319 & 0.010 \\
\hline $\mathrm{N}$ obs. & 187 & 187 & 187 & 185 & 187 \\
\hline
\end{tabular}

Notes: The table reports GMM-SYS 2-step dynamic panel data results with an advisor's performance as the dependent variable. The instrument set includes from $\mathrm{t}-2$ to $\mathrm{t}-4$ lags of advisor-specific variables. Year dummy variable are included but not reported. Robust standard errors are in parentheses. ", ', '"* represent the 10, 5 , and 1 percent significance level, respectively. 
Table B4. Transition Matrices

\begin{tabular}{|c|c|c|c|c|}
\hline & $\begin{array}{c}\text { Level } \\
\text { Bad } \\
t-1\end{array}$ & $\begin{array}{c}\text { ROA } \\
\text { Med } \\
t-1\end{array}$ & $\begin{array}{c}\text { Good } \\
t-1\end{array}$ & $\begin{array}{c}\text { Total } \\
t-1\end{array}$ \\
\hline Bad $t$ & 27 & 19 & 0 & 46 \\
\hline Neutral $t$ & 31 & 237 & 60 & 328 \\
\hline Good $t$ & 0 & 17 & 68 & 85 \\
\hline \multirow[t]{2}{*}{ Total $t$} & 58 & 273 & 128 & 459 \\
\hline & $\begin{array}{c}\text { Level } \\
\text { Bad } \\
t-1\end{array}$ & $\begin{array}{c}\text { ROE } \\
\text { Med } \\
t-1\end{array}$ & $\begin{array}{c}\text { Good } \\
t-1\end{array}$ & $\begin{array}{c}\text { Total } \\
t-1\end{array}$ \\
\hline Bad $t$ & 27 & 25 & 0 & 52 \\
\hline Neutral $t$ & 33 & 276 & 48 & 357 \\
\hline Good $t$ & 0 & 22 & 28 & 50 \\
\hline \multirow[t]{2}{*}{ Total $t$} & 60 & 323 & 76 & 459 \\
\hline & $\begin{array}{c}\text { Level } \\
\text { Bad } \\
t-1 \\
\end{array}$ & $\begin{array}{c}\text { OP/TA } \\
\text { Med } \\
t-1\end{array}$ & $\begin{array}{c}\text { Good } \\
t-1\end{array}$ & $\begin{array}{c}\text { Total } \\
t-1\end{array}$ \\
\hline Bad $t$ & 16 & 25 & 0 & 41 \\
\hline Neutral $t$ & 31 & 248 & 67 & 346 \\
\hline Good $t$ & 0 & 17 & 55 & 72 \\
\hline \multirow[t]{2}{*}{ Total $t$} & 47 & 290 & 122 & 459 \\
\hline & $\begin{array}{c}\text { Level } \\
\text { Bad } \\
t-1\end{array}$ & $\begin{array}{c}\text { ROS } \\
\text { Med } \\
t-1\end{array}$ & $\begin{array}{c}\text { Good } \\
t-1\end{array}$ & $\begin{array}{c}\text { Total } \\
t-1\end{array}$ \\
\hline Bad $t$ & 32 & 24 & 0 & 56 \\
\hline Neutral $t$ & 21 & 246 & 65 & 332 \\
\hline Good $t$ & 0 & 23 & 48 & 71 \\
\hline \multirow[t]{2}{*}{ Total $t$} & 53 & 293 & 113 & 459 \\
\hline & $\begin{array}{c}\text { Level } \\
\text { Bad } \\
t-1\end{array}$ & $\begin{array}{c}\text { Tob Q } \\
\text { Med } \\
t-1\end{array}$ & $\begin{array}{c}\text { Good } \\
t-1\end{array}$ & $\begin{array}{c}\text { Total } \\
t-1\end{array}$ \\
\hline $\operatorname{Bad} t$ & 64 & 22 & 0 & 86 \\
\hline Neutral $t$ & 68 & 221 & 33 & 322 \\
\hline Good $t$ & 0 & 10 & 41 & 51 \\
\hline Total $t$ & 132 & 253 & 74 & 459 \\
\hline
\end{tabular}

\begin{tabular}{|c|c|c|c|c|}
\hline & $\begin{array}{c}\text { Diff } \\
\text { Bad } \\
t-1\end{array}$ & $\begin{array}{c}\text { ROA } \\
\text { Med } \\
t-1\end{array}$ & $\begin{array}{c}\text { Good } \\
t-1\end{array}$ & $\begin{array}{c}\text { Total } \\
t-1\end{array}$ \\
\hline Bad $t$ & 17 & 20 & 0 & 37 \\
\hline Neutral $t$ & 48 & 276 & 42 & 366 \\
\hline Good $t$ & 0 & 33 & 23 & 56 \\
\hline \multirow[t]{2}{*}{ Total $t$} & 65 & 329 & 65 & 459 \\
\hline & $\begin{array}{c}\text { Diff } \\
\text { Bad } \\
t-1\end{array}$ & $\begin{array}{c}\text { ROE } \\
\text { Med } \\
t-1\end{array}$ & $\begin{array}{c}\text { Good } \\
t-1\end{array}$ & $\begin{array}{c}\text { Total } \\
t-1\end{array}$ \\
\hline Bad $t$ & 13 & 27 & 0 & 40 \\
\hline Neutral $t$ & 50 & 284 & 32 & 366 \\
\hline Good $t$ & 0 & 24 & 29 & 53 \\
\hline \multirow[t]{2}{*}{ Total $t$} & 63 & 335 & 61 & 459 \\
\hline & $\begin{array}{c}\text { Diff } \\
\text { Bad } \\
t-1\end{array}$ & $\begin{array}{c}\text { OP/TA } \\
\text { Med } \\
t-1\end{array}$ & $\begin{array}{c}\text { Good } \\
t-1\end{array}$ & $\begin{array}{c}\text { Total } \\
t-1\end{array}$ \\
\hline Bad $t$ & 15 & 20 & 0 & 35 \\
\hline Neutral $t$ & 41 & 286 & 46 & 373 \\
\hline Good $t$ & 0 & 37 & 14 & 51 \\
\hline \multirow[t]{2}{*}{ Total $t$} & 56 & 343 & 60 & 459 \\
\hline & $\begin{array}{c}\text { Diff } \\
\text { Bad } \\
t-1\end{array}$ & $\begin{array}{c}\text { ROS } \\
\text { Med } \\
t-1\end{array}$ & $\begin{array}{c}\text { Good } \\
t-1\end{array}$ & $\begin{array}{c}\text { Total } \\
t-1\end{array}$ \\
\hline Bad $t$ & 15 & 20 & 0 & 35 \\
\hline Neutral $t$ & 33 & 301 & 47 & 381 \\
\hline Good $t$ & 0 & 29 & 14 & 43 \\
\hline \multirow[t]{2}{*}{ Total $t$} & 48 & 350 & 61 & 459 \\
\hline & $\begin{array}{c}\text { Diff } \\
\text { Bad } \\
t-1\end{array}$ & $\begin{array}{c}\text { Tob Q } \\
\text { Med } \\
t-1\end{array}$ & $\begin{array}{c}\text { Good } \\
t-1\end{array}$ & $\begin{array}{c}\text { Total } \\
t-1\end{array}$ \\
\hline Bad $t$ & 10 & 17 & 0 & 27 \\
\hline Neutral $t$ & 39 & 261 & 63 & 363 \\
\hline Good $t$ & 0 & 29 & 40 & 69 \\
\hline Total $t$ & 49 & 307 & 103 & 459 \\
\hline
\end{tabular}

Notes: The table shows transition matrices for company switches among 'good', 'bad', and 'neutral' states. An advisor is defined as 'good' if it has been above average for the last two years; 'bad' if it has been below average for the last two years; and 'neutral' if it has flip-flopped between the two. The performance of advisors, fixed effects, is calculated based on either levels or different company performance measures (ROA, ROE, ROS, Operating Income/Total Assets, and Tobin's Q). 
Table B5. Determinants of Advisor Switches, Level-Based Advisors' Effects

Panel A:

\begin{tabular}{|c|c|c|c|c|c|}
\hline & $\begin{array}{c}\text { ROA } \\
\text { (1) }\end{array}$ & $\begin{array}{c}\text { ROE } \\
(2) \\
\end{array}$ & $\begin{array}{c}\text { OP/TA } \\
\text { (3) }\end{array}$ & $\begin{array}{c}\text { ROS } \\
(4)\end{array}$ & $\begin{array}{c}\text { Tobin's Q } \\
\text { (5) }\end{array}$ \\
\hline Performance $_{t-1}$ & $\begin{array}{l}-0.015^{*} \\
(0.009)\end{array}$ & $\begin{array}{c}-0.001 \\
(0.003)\end{array}$ & $\begin{array}{l}-0.018^{*} \\
(0.010)\end{array}$ & $\begin{array}{l}-0.009^{*} \\
(0.005)\end{array}$ & $\begin{array}{l}0.000 \\
(0.001)\end{array}$ \\
\hline Advisor $\mathrm{FE}_{t-1}(\hat{\beta})$ & $\begin{array}{c}0.014 \\
(0.014)\end{array}$ & $\begin{array}{c}0.001 \\
(0.002)\end{array}$ & $\begin{array}{l}-0.009 \\
(0.015)\end{array}$ & $\begin{array}{l}0.026^{*} \\
(0.015)\end{array}$ & $\begin{array}{l}-0.000 \\
(0.001)\end{array}$ \\
\hline $\log (\text { Firms })_{t-1}$ & $\begin{array}{l}-0.014^{* * *} \\
(0.005)\end{array}$ & $\begin{array}{l}-0.014^{* * *} \\
(0.005)\end{array}$ & $\begin{array}{l}-0.013^{* * *} \\
(0.005)\end{array}$ & $\begin{array}{l}-0.015^{* * *} \\
(0.006)\end{array}$ & $\begin{array}{l}-0.014^{* * *} \\
(0.005)\end{array}$ \\
\hline Log (Total Assets) $)_{t-1}$ & $\begin{array}{c}0.000 \\
(0.001)\end{array}$ & $\begin{array}{l}-0.001 \\
(0.001)\end{array}$ & $\begin{array}{c}0.000 \\
(0.001)\end{array}$ & $\begin{array}{l}-0.000 \\
(0.001)\end{array}$ & $\begin{array}{l}-0.000 \\
(0.001)\end{array}$ \\
\hline Leverage $_{t-1}$ & $\begin{array}{c}0.001 \\
(0.005)\end{array}$ & $\begin{array}{c}0.003 \\
(0.006)\end{array}$ & $\begin{array}{c}0.002 \\
(0.005)\end{array}$ & $\begin{array}{c}0.004 \\
(0.006)\end{array}$ & $\begin{array}{c}0.002 \\
(0.005)\end{array}$ \\
\hline Pseudo $\mathrm{R}^{2}$ & 0.069 & 0.066 & 0.069 & 0.069 & 0.066 \\
\hline N obs. & 2,879 & 2,879 & 2,879 & 2,843 & 2,858 \\
\hline
\end{tabular}

Panel B:

\begin{tabular}{|c|c|c|c|c|c|}
\hline & $\begin{array}{c}\text { ROA } \\
\text { (1) }\end{array}$ & $\begin{array}{c}\text { ROE } \\
(2)\end{array}$ & $\begin{array}{c}\text { OP/TA } \\
\text { (3) }\end{array}$ & $\begin{array}{l}\text { ROS } \\
(4)\end{array}$ & $\begin{array}{c}\text { Tobin's Q } \\
\text { (5) }\end{array}$ \\
\hline Performance $_{t-1}$ & $\begin{array}{l}-0.038^{*} \\
(0.023)\end{array}$ & $\begin{array}{l}-0.000 \\
(0.010)\end{array}$ & $\begin{array}{l}-0.050 \text { ** } \\
(0.024)\end{array}$ & $\begin{array}{l}-0.018 \\
(0.013)\end{array}$ & $\begin{array}{c}0.003 \\
(0.003)\end{array}$ \\
\hline Advisor Good Go $_{t-1}$ & $\begin{array}{l}-0.024^{* * *} \\
(0.007)\end{array}$ & $\begin{array}{l}-0.027^{* * *} \\
(0.008)\end{array}$ & $\begin{array}{l}-0.019^{* *} \\
(0.008)\end{array}$ & $\begin{array}{l}-0.017^{* *} \\
(0.008)\end{array}$ & $\begin{array}{l}-0.034^{* * *} \\
(0.009)\end{array}$ \\
\hline Advisor Badt B $_{t-1}$ & $\begin{array}{l}-0.013 \\
(0.011)\end{array}$ & $\begin{array}{l}-0.010 \\
(0.010)\end{array}$ & $\begin{array}{l}0.046^{* *} \\
(0.023)\end{array}$ & $\begin{array}{c}-0.003 \\
(0.011)\end{array}$ & $\begin{array}{l}-0.020^{* *} \\
(0.009)\end{array}$ \\
\hline $\log (\text { Firms })_{t-1}$ & $\begin{array}{c}-0.040^{* * *} \\
(0.007)\end{array}$ & $\begin{array}{l}-0.041^{* * *} \\
(0.007)\end{array}$ & $\begin{array}{c}-0.038^{* * *} \\
(0.006)\end{array}$ & $\begin{array}{c}-0.039^{* * *} \\
(0.007)\end{array}$ & $\begin{array}{l}-0.041^{* * *} \\
(0.007)\end{array}$ \\
\hline Log (Total Assets) $)_{t-1}$ & $\begin{array}{c}0.004 \\
(0.002)\end{array}$ & $\begin{array}{c}0.002 \\
(0.002)\end{array}$ & $\begin{array}{c}0.004 \\
(0.002)\end{array}$ & $\begin{array}{c}0.002 \\
(0.002)\end{array}$ & $\begin{array}{c}0.004 \\
(0.003)\end{array}$ \\
\hline Leverage $_{t-1}$ & $\begin{array}{l}0.009 \\
(0.017)\end{array}$ & $\begin{array}{c}0.014 \\
(0.016)\end{array}$ & $\begin{array}{c}0.008 \\
(0.016)\end{array}$ & $\begin{array}{c}0.011 \\
(0.017)\end{array}$ & $\begin{array}{c}0.011 \\
(0.017)\end{array}$ \\
\hline Pseudo $\mathrm{R}^{2}$ & 0.054 & 0.051 & 0.055 & 0.049 & 0.054 \\
\hline $\mathrm{N}$ obs. & 4,021 & 4,021 & 4,019 & 3,932 & 3,994 \\
\hline
\end{tabular}

Note: The dependent variable is a binary measure equal to one if there was a switch of an advisor between period $t-1$ and $t$. Marginal effects estimated around mean points are reported. Robust standard errors are in parentheses. ", ", " represent the 10, 5, and 1 percent significance level, respectively. 
Table B6. Determinants of Advisor Switches, Difference-Based Advisor Effects

Panel A:

\begin{tabular}{|c|c|c|c|c|c|}
\hline & $\begin{array}{c}\text { ROA } \\
\text { (1) }\end{array}$ & $\begin{array}{l}\text { ROE } \\
\text { (2) }\end{array}$ & $\begin{array}{c}\text { OP/TA } \\
\text { (3) }\end{array}$ & $\begin{array}{l}\text { ROS } \\
(4)\end{array}$ & $\begin{array}{c}\text { Tobin's Q } \\
\text { (5) }\end{array}$ \\
\hline Performance $_{t-1}$ & $\begin{array}{c}0.005 \\
(0.009)\end{array}$ & $\begin{array}{c}0.005 \\
(0.003)\end{array}$ & $\begin{array}{c}-0.009 \\
(0.011)\end{array}$ & $\begin{array}{c}0.009 \\
(0.007)\end{array}$ & $\begin{array}{l}-0.000 \\
(0.002)\end{array}$ \\
\hline Advisor $\mathrm{FE}_{t-1}(\hat{\gamma})$ & $\begin{array}{c}0.025 \\
(0.029)\end{array}$ & $\begin{array}{c}0.018 \\
(0.012)\end{array}$ & $\begin{array}{l}-0.054 \\
(0.038)\end{array}$ & $\begin{array}{l}-0.005 \\
(0.020)\end{array}$ & $\begin{array}{c}-0.001 \\
(0.005)\end{array}$ \\
\hline $\log (\text { Firms })_{t-1}$ & $\begin{array}{l}-0.013^{* *} \\
(0.006)\end{array}$ & $\begin{array}{l}-0.012^{* *} \\
(0.005)\end{array}$ & $\begin{array}{l}-0.012^{* *} \\
(0.005)\end{array}$ & $\begin{array}{l}-0.012^{* *} \\
(0.005)\end{array}$ & $\begin{array}{l}-0.012^{* * *} \\
(0.002)\end{array}$ \\
\hline Log (Total Assets) $)_{t-1}$ & $\begin{array}{l}-0.001 \\
(0.001)\end{array}$ & $\begin{array}{l}-0.001 \\
(0.001)\end{array}$ & $\begin{array}{l}-0.001 \\
(0.001)\end{array}$ & $\begin{array}{l}-0.001 \\
(0.001)\end{array}$ & $\begin{array}{l}-0.001 \\
(0.001)\end{array}$ \\
\hline Leverage $_{t-1}$ & $\begin{array}{c}0.003 \\
(0.005)\end{array}$ & $\begin{array}{c}0.001 \\
(0.005)\end{array}$ & $\begin{array}{c}0.002 \\
(0.005)\end{array}$ & $\begin{array}{c}0.004 \\
(0.005)\end{array}$ & $\begin{array}{c}0.002 \\
(0.005)\end{array}$ \\
\hline Pseudo $\mathrm{R}^{2}$ & 0.072 & 0.077 & 0.071 & 0.076 & 0.071 \\
\hline N obs. & 2,751 & 2,751 & 2,749 & 2,679 & 2,731 \\
\hline
\end{tabular}

Panel B:

\begin{tabular}{|c|c|c|c|c|c|}
\hline & $\begin{array}{c}\text { ROA } \\
\text { (1) }\end{array}$ & $\begin{array}{c}\text { ROE } \\
(2)\end{array}$ & $\begin{array}{c}\text { OP/TA } \\
\text { (3) }\end{array}$ & $\begin{array}{l}\text { ROS } \\
(4)\end{array}$ & $\begin{array}{c}\text { Tobin's Q } \\
\text { (5) }\end{array}$ \\
\hline Performance $_{t-1}$ & $\begin{array}{c}0.007 \\
(0.009)\end{array}$ & $\begin{array}{c}0.007^{*} \\
(0.004)\end{array}$ & $\begin{array}{l}-0.010 \\
(0.011)\end{array}$ & $\begin{array}{c}0.010 \\
(0.007)\end{array}$ & $\begin{array}{c}0.001 \\
(0.002)\end{array}$ \\
\hline Advisor Good G $_{t-1}$ & $\begin{array}{l}-0.004 \\
(0.003)\end{array}$ & $\begin{array}{l}-0.003 \\
(0.003)\end{array}$ & $\begin{array}{c}0.003 \\
(0.004)\end{array}$ & $\begin{array}{l}-0.002 \\
(0.004)\end{array}$ & $\begin{array}{l}-0.002 \\
(0.003)\end{array}$ \\
\hline Advisor Badt Ba $_{t-1}$ & $\begin{array}{l}-0.004 \\
(0.003)\end{array}$ & $\begin{array}{l}-0.007^{*} \\
(0.004)\end{array}$ & $\begin{array}{l}-0.000 \\
(0.003)\end{array}$ & $\begin{array}{l}-0.007^{*} \\
(0.004)\end{array}$ & $\begin{array}{l}-0.005 \\
(0.004)\end{array}$ \\
\hline $\log (\text { Firms })_{t-1}$ & $\begin{array}{l}-0.012^{* *} \\
(0.005)\end{array}$ & $\begin{array}{l}-0.012^{* *} \\
(0.005)\end{array}$ & $\begin{array}{l}-0.011^{* *} \\
(0.005)\end{array}$ & $\begin{array}{l}-0.012^{* *} \\
(0.006)\end{array}$ & $\begin{array}{l}-0.012^{* *} \\
(0.005)\end{array}$ \\
\hline Log (Total Assets) $)_{t-1}$ & $\begin{array}{l}-0.001 \\
(0.001)\end{array}$ & $\begin{array}{l}-0.001 \\
(0.001)\end{array}$ & $\begin{array}{l}-0.001 \\
(0.001)\end{array}$ & $\begin{array}{l}-0.001 \\
(0.001)\end{array}$ & $\begin{array}{l}-0.001 \\
(0.001)\end{array}$ \\
\hline Leverage $_{t-1}$ & $\begin{array}{c}0.003 \\
(0.005)\end{array}$ & $\begin{array}{c}0.001 \\
(0.005)\end{array}$ & $\begin{array}{c}0.002 \\
(0.005)\end{array}$ & $\begin{array}{c}0.005 \\
(0.006)\end{array}$ & $\begin{array}{c}0.001 \\
(0.005)\end{array}$ \\
\hline Pseudo $\mathrm{R}^{2}$ & 0.072 & 0.078 & 0.071 & 0.077 & 0.070 \\
\hline $\mathrm{N}$ obs. & 2,449 & 2,449 & 2,447 & 2,411 & 2,431 \\
\hline
\end{tabular}

Note: The dependent variable is a binary measure equal to one if there was a switch of advisor between period $t-1$ and $t$. Marginal effects estimated around mean points are reported. Robust standard errors are in parentheses. ", ," 
Table B7. Differences in Variables Before and After an Advisor Change

Panel A: Advisor Based Variables

\begin{tabular}{|c|c|c|c|c|c|c|c|c|}
\hline \multirow{2}{*}{ Variable } & \multicolumn{3}{|c|}{ Before } & \multicolumn{3}{|c|}{ Before } & \multirow[t]{2}{*}{ Diff: } & \multirow[t]{2}{*}{ p-value } \\
\hline & Mean & SD & $\mathbf{N}$ & Mean & SD & $\mathbf{N}$ & & \\
\hline$\hat{\beta}$ (level ROA) & 0.01 & 0.06 & 321 & 0.01 & 0.08 & 321 & 0.00 & 0.94 \\
\hline$\hat{\beta}$ (level ROE) & -0.03 & 0.16 & 321 & -0.02 & 0.52 & 321 & -0.02 & 0.59 \\
\hline$\hat{\beta}$ (level OP/TA) & 0.01 & 0.06 & 321 & 0.01 & 0.08 & 321 & 0.00 & 0.52 \\
\hline$\hat{\beta}$ (level ROS) & 0.02 & 0.09 & 319 & 0.01 & 0.10 & 319 & 0.01 & 0.32 \\
\hline$\hat{\beta}$ (level TobinsQ) & -0.15 & 0.49 & 321 & -0.09 & 0.77 & 321 & -0.06 & 0.19 \\
\hline$\hat{\gamma}(\operatorname{diff} \mathrm{ROA})$ & 0.00 & 0.05 & 321 & 0.01 & 0.05 & 321 & -0.00 & 0.48 \\
\hline$\hat{\gamma}$ (diff ROE) & 0.01 & 0.11 & 321 & 0.02 & 0.20 & 321 & -0.01 & 0.64 \\
\hline$\hat{\gamma}(\operatorname{diff} \mathrm{OP} / \mathrm{TA})$ & -0.01 & 0.04 & 321 & -0.01 & 0.05 & 321 & -0.00 & 0.99 \\
\hline$\hat{\gamma}$ (diff ROS) & 0.01 & 0.07 & 319 & 0.00 & 0.07 & 319 & 0.00 & 0.34 \\
\hline$\hat{\gamma}$ (diff TobinsQ) & 0.01 & 0.22 & 321 & 0.03 & 0.21 & 321 & -0.02 & 0.19 \\
\hline Log (Firms Total) & 3.13 & 0.88 & 398 & 3.11 & 0.85 & 398 & 0.01 & 0.82 \\
\hline
\end{tabular}

Panel B: Firm-Based Variables

\begin{tabular}{lcccccccc}
\hline Variable & & Before & & & Before & & Diff: & p-value \\
& Mean & SD & N & Mean & SD & N & \\
\hline ROA (level) & -0.03 & 0.20 & 398 & -0.02 & 0.19 & 398 & -0.00 & 0.74 \\
ROE (level) & -0.02 & 0.40 & 398 & -0.00 & 0.41 & 398 & -0.02 & 0.44 \\
OP/TA (level) & 0.03 & 0.19 & 398 & 0.03 & 0.19 & 398 & -0.00 & 0.68 \\
ROS (level) & -0.08 & 0.34 & 382 & -0.08 & 0.33 & 382 & -0.00 & 0.94 \\
TobinsQ (level) & 1.76 & 1.12 & 395 & 1.82 & 1.17 & 395 & -0.05 & 0.20 \\
& & & & & & & & \\
ROA (diff) & -0.00 & 0.14 & 275 & 0.01 & 0.15 & 275 & -0.01 & 0.53 \\
ROE (diff) & -0.00 & 0.46 & 275 & 0.07 & 0.48 & 275 & -0.07 & 0.13 \\
OP/TA (diff) & 0.00 & 0.12 & 275 & -0.00 & 0.13 & 275 & 0.01 & 0.59 \\
ROS (diff) & -0.01 & 0.22 & 265 & 0.04 & 0.21 & 265 & -0.04 & 0.03 \\
Tobin's Q (diff) & -0.01 & 0.72 & 274 & -0.02 & 0.77 & 274 & 0.01 & 0.87 \\
\hline
\end{tabular}

Notes: The table reports descriptive statistics for key firm-specific and advisor-specific variables before and after switching advisors. P-value is the $\mathrm{p}$-value for t-test of mean comparison. 